\title{
EFFECT OF SOME MICROELEMENTS AND GROWTH SUBSTANCES ON THE DEFOLIATION PHENOMENA IN SOME FABA BEAN CULTIVARS
}

\author{
EL-Refaey, R. A. ${ }^{1}$; U. A. Abdel-Razek ${ }^{1}$, A. M. EL-Garhy ${ }^{2}$ \\ andM. K. S. Ahmed ${ }^{3}$ \\ ${ }^{1}$ Agron. Dept., Fac.of Agric., Tanta Univ. EL-Gharbia, Egypt. ${ }^{2}$ Food \\ legume Research Section -Field Crops Research Institute -A.R.C. \\ EL-Giza, Egypt. ${ }^{3}$ Post Graduate student, Agron. Dept., Fac. Of \\ Agric., Tanta Univ. EL-Gharbia, Egypt.
}

\begin{abstract}
The present study was carried out at Itay EL-Baroud Agriculture Research Station, EL-Behaira governorate, Egypt during two agricultural seasons of $2012 / 13$ and 2013/14. Three faba bean cultivars (Nubaria 1, Giza 716 and Sakha 1) were used to study the effects of five commercial growth substances (DotraFirt, Dotra Micro Plus, Dotra Frost, Crop Plus and the control) on leaf area index $\left(\mathrm{cm}^{2}\right)$, leaf fresh weight/plant $(\mathrm{g})$, leaf dry weight/plant (g),fresh and dry stem weights/plant $(\mathrm{g})$, total flowers/ plant, percentage of buds shedding/plant. The three faba bean cultivars were sown in a split plot design with three replications.

The results indicate that, significant differences were detected among all used cultivars, growth substances treatments and their interactions in all studied traits in both seasons, except for the cultivars effect and their interaction on leaf area index in both seasons. The cultivar Nubaria 1 expressed the best desirable mean values for total flowers/plant, Total shedding of buds/plant and most vegetative traits in both seasons.While, the cultivar Giza 716 gave the best desirable mean values for Total flowers/plant in both seasons. The growth substance Crop plus showed the most desirable effect on total flowers/plant and expressed the second good treatment for reducing the percentage of total shedding of buds/plant in both seasons, while the growth substance Dotra micro plus had good desirable effect on total flowers/plant and total shedding of buds/plant in both seasons. The Dotrafirt treatment had undesirable effect on total shedding of buds/plant in both seasons. Farmers in Delta conditions can use the two faba bean cultivars Giza 716 and Nubaria 1 to obtain the highest number of flowers and the lowest percentage of total shedding of buds/plant. The two growth substances Crop plus and Dotra micro plus could be used to obtained for the highest vegetative growth under Delta conditions.
\end{abstract}

Key words:faba bean- growth substances-vegetativegrowth - bud shedding. 


\section{INTRODUCTION}

Faba bean is an annual legume known botanically as Vicia faba. L. The origin of faba beans is obscure, but the best information indicates in the Mediterranean area. Faba beans have been found in the earliest human settlements; remains are reported to have been found in Egyptian tombs. In Egypt, the beans were considered commoner food and were shunned by the upper classes (Hornykiewicz,2010). The harvested area in Egypt was 120000 hectares and the production quantity was 450000 tons in 2013* season, this quantity cover about $6 \%$ from the local consumption. Legumes require neutral to alkaline soil for maximum $\mathrm{N}$ fixation by nodule bacteria. Soils should be tested and, if necessary, limed to at least pH. 6.0. Bolo mitic limestone would need to be applied at least one year prior to faba bean production. Soils need to have $p$ and $k$ soil test levels in the medium to high range to ensure adequate fertility levels for maximum crop yields. These soil test levels are at least 11 ppm $\mathrm{p}$ and $81 \mathrm{ppm} \mathrm{k}$ depending on subsoil category. Soils should be tested and, if necessary, amended with $\mathrm{P}_{2} \mathrm{O}_{5}$ and/or $\mathrm{k}_{2} \mathrm{O}$ prior to seeding. Nutrients equivalent to crop removal should be applied annually in order to maintain adequate soil test levels. Faba bean is similar in growth requirements and yields to canning peas. If top growth is removed for silage, higher applications are needed. Some $\mathrm{N}$ may be needed to ensure a good start since faba bean is a shallow rooted annual legume planted very early. Sixteen plant food nutrients are essential for proper crop development. Each is equally important to the plant, yet each is required in vastly different amounts. These differences have led to the grouping of these essential elements into three categories; primary (macro) nutrients, secondary nutrients, and micronutrients. Anna Kocoń (2010).

Primary macro nutrients are nitrogen, phosphorus, and potassium. They are the most frequently required in a crop fertilization program. Also, they are need in the greatest total quantity by plants as fertilizer. The secondary nutrients are calcium, magnesium, and sulphur. For most crops, these three nutrients are needed in lesser amounts that the primary nutrients. They are growing in importance in crop fertilization programs due to more stringent clean air standards and efforts to improve the environment. The micronutrients are boron, chlorine, cooper, iron, manganese, molybdenum, and zinc. These plant food elements are used in very small amounts, but they are just as important to plant development and profitable crop production as the major nutrients. Especially, they work "behind the scene" as activators of many plant functions Davood (2013). 
The aims of this study were to estimate the effect of some micro elements (growth substances) on vegetative growth traits and total number of flower/plant, percentage of total buds shedding /plant and some of three faba bean cultivars to determine the best cultivar and the best growth substances that may use under Delta condition to improve the amount of flowers/plant and reduce the percentage of total buds shedding/plant and these will increase seed yield.

\section{MATERIALS AND METHODS}

The present study was carried out at Itay EL-Baroud Agriculture Research Farm, EL-Behaira governorate, Egypt during the two agriculture seasons of 2012/13 and 2013/14.

Three faba bean varieties Nubaria 1, Giza 716 and Sakha 1 were used in the present study to examine agronomical traits and chemical components under five commercial substances (DotraFirt, Dotra Micro Plus, Dotra Frost, Crop Plus and control).

The commercial name, chemical component of the five growth substances are presented in Table 1.

*(FAO STAT, 2013)

Table 1: The commercial name, chemical component of the four growth substances (DotraFirt, Dotra Micro Plus, Dotra Frost, Crop Plus) and control

\begin{tabular}{|l|l|l|l|}
\hline $\begin{array}{l}\text { Code } \\
\text { number }\end{array}$ & Commercial name & Chemical components & Added rate/ faddan \\
\hline 1 & DotraFirt & $19 \% \mathrm{~N}+19 \% \mathrm{P}+19 \% \mathrm{~K}+4.14 \% \mathrm{~S}$ & 2.5 (kg/faddan) \\
\hline 2 & Dotra Micro Plus & $2 \% \mathrm{Zn}+4 \% \mathrm{Fe}+2 \% \mathrm{Mn}$. & 1 (later $/$ faddan) \\
\hline 3 & Dotra Frost & $3 \% \mathrm{~B}+1 \% \mathrm{Mo}$ & 250 (ml later/ faddan) \\
\hline 4 & Crop Plus & $\begin{array}{l}1.2 \% \text { cytokinen }+0.8 \% \text { Oxcine }+3 \% \mathrm{Zn}+1.7 \% \mathrm{Fe}+1.4 \\
\% \mathrm{Mn}+1.3 \% \mathrm{Cu}+4.5 \% \mathrm{~S}+9 \% \mathrm{Citric} \text { acid }\end{array}$ & 250 (ml later/ faddan) \\
\hline 5 & Control & Without any add. & Without any added \\
\hline
\end{tabular}

In the first season 2012/13, the three faba bean cultivars were sown in 15 October 2012 and evaluated in a split plot design with three replications. The plot area was 5 ridges. 4 meters long and 0.6 meters apart. Seeds were sown on two side of the ridge at $15 \mathrm{~cm}$ hill spacing with one seed per hill. The dry sowing method called afer was used and all the other cultural practices were followed as recommended. Meanwhile, the growth substances were sprayed two times after 60 and 80 days from sowing. The following measurements were recorded on individual plants basis at harvest. Data were recorded as average of 4 individual random plants chosen from each sub plot. In the second season 2013/14 the experiment was repeated with the same procedure. The vegetative growth characteristics were as follows:

1- Leaf area index: the average area of all leaves of plant.

2- Leaf Fresh Weight (g): the average weight of all fresh leaves / plant $(\mathrm{g})$. 
3- Leaf Dry Weight (g): the average weight of all dry leaves / plant (g).

4- Fresh Stem Weight (g): the average weight of all fresh stems / plant $(\mathrm{g})$.

5- Total Flowers /plant.

6- Total Shedding of buds /plant.

7- Dry Stem Weight (g): the average weight of all dry leaves / plant (g).

\section{Statistical analysis:}

Results were expressed as mean \pm standard error (SE). The data were analyzed by using Two-way ANOVA followed by LSD test through SPSS 16 (version 4). The treatment means were compared using least significant difference (LSD) tested at level of probability $5 \%$ and 1\%, respectively as described by Gomez and Gomez (1984).

\section{RESULTS AND DISCUSSIONS \\ The results in this work could be divided as follows:}

CULTIVARS EFFECTS:

It could be clear from the results showing in Table 2 and Fig. $1,3,4,6,8,10$ and 12 that,Nubaria $1 \mathrm{cv}$. had highly significant desirable mean values for number of total flowers/ plant, leaf fresh weight /plant (g)and leaf dry weight/plant(g), in the first season, while in second one, the same variety had highly significant difference in desirable direction for percentage of total buds shedding /plant and leaf dry weight / plant. However, Giza 716 surpassed the other two varieties with respect to no.of total flowers / plant in the second season only. On the other hand, Sakha 1 had highly significant difference than the other cultivars with respect to percentage of total buds shedding/plant in the first season, leaf fresh and dry weights/plant in both seasons and fresh stem weight/plant in the second season.

The superiority of the cultivar Sakha 1 for vegetative traits has been reported by many researchers before such as; Talaat,Neveen andAbdallah (2008)where they indicated the significantly surpassed of Sakha 1 cultivar in dry weight of nodules, leaves number, shoot dry weight, leaf area, compared with some commercial cultivars.Kandil et al. (2011) found that, Sakha 1 cultivar produced the lowest buds shedding percentage compared with Giza 716. The same trends about the differences between genotypes in vegetative parameters were obtained by Ibrahim et al. (1995), Magdi (2011), Sadak,Mervat et al. (2013), Abd el-Azeem et al. (2014) and Khalil et al. (2015). 


\section{GROWTH SUBSTANCES EFFECT:}

From the results shown inTable 2 and Fig. 2, 4, 5, 7,9,11 and 13 , it could be clear that, differences between all growth substances i.e.(Crop plus, Dotra frost, Dotra micro plus, Dotrafirt and the control treatment) were highly significant for all vegetative traits in both seasons, except leaf area index in the first season, where the differences were only significant. However, Crop plus treatment significantly exceeded all the other treatments for number of total flowers/ plant, leaf area index $\left(\mathrm{cm}^{2}\right)$, leaf fresh weight /plant $(\mathrm{g})$, leaf dry weight/plant (g),fresh stem weight/plant(g)and dry stem weight/plant(g) in both seasons. While,Dotra frost treatment recognized the lowest shedding percentage of buds/plant in both seasons. Moreover, Dotra micro plus treatment exhibited the second one in increasing total flowers/plant, leaf area index $\left(\mathrm{cm}^{2}\right)$, leaf fresh weight/plant(g), leaf dry weight/plant(g), fresh and dry stem weight/plant $(\mathrm{g})$ in both seasons compared with the control. The control treatment seemed to be the worst among all treatments in all vegetative growth parameters.

Generally, the growth substances such as Crop plus and Dotra micro plus play a major role in achieve plant efficiency in accumulation and building. These results were in agreement with those reported by Hegazy et al. (1992) where they indicated that, most Vicia faba characteristics were increased by a single addition of $\mathrm{Fe}$ or $\mathrm{Mn}$ or $\mathrm{Zn}$ or Mo or a mixture of them, Shehata and Bondok (1996) found that, all the growth regulator treatments reduced shedding percentage and promoted pod setting compared with the control. Mahmoud et al. (2006) showed that, boron foliar fertilization has significantly increased leaf area, total dry weight and Mady (2009), found that, foliar application with yeast extract and zinc either individually or in mixture significantly increased many growth aspects such as number of leaves per plant, dry weights of both stems and leaves per plant and total leaf area.

The interactions: Through the results shown in Table 3 , it could be observed the significantly differences of the interaction between cultivars, and growth substances for number of total flowers/plant, shedding percentage of buds/plant, leaf fresh weight/plant $(\mathrm{g})$, leaf dry weight/plant(g) and fresh and dry stem weights/plant(g) in both seasons. The highest values of the interactions were presented for total number of flowers / plant in the combinations of Crop plus and Dotramicro plus with each of the three cultivars i.e. Crop plus $x$ Nubaria 1, Crop plus x Giza 716, Crop plus x Sakha 1, Dotramicro plus x Nubaria 1, Dotramicro plus x Giza 716 and Dotramicro plus x Sakha 1 where these interactions had the highly significant mean values in this respect in the first season. While in the second season, the 
interaction of Crop plus with Giza $716 \mathrm{cv}$.gave the highest value of total number of flowers / plant. With respect to percentage of buds shedding / plant, the results in Table 3 indicated that, the interaction between cultivars and growth substances revealed that the combinations of Crop plus with the three cultivars from one side and Dotra frost with the three cultivars from the other side gave the significantly lowest values in this concern in the first season. While in the second season, the lowest values of percentage of buds shedding /plant was recognized when the control treatment interacted with Nubaria1cv.for leaf fresh weight/plant. The growth substances i.e.Crop Plus when interacted with each of the three cultivars used in the study gave the significantly highest values in both seasons. However, the second interaction in this concern was Dotra Micro Plus with each of the three cultivars for leaf dry weight /plant. The interaction between Crop Plus with Nubaria $1 \mathrm{cv}$.had the significantly highest values in both seasons with regard to fresh stem weight/plant and dry stem weight/plant. It could be noted that, the interaction, Crop Plus $x$ Nubaria 1, Crop Plus x Giza 716 and crop Plus x Sakha 1 ranked the first interaction which gave the significantly highest values for both traits in both seasons. However, there was no significant difference between the three interactions with respect to fresh and dry weights / plant.This indicated that, the three cultivars have a different response to the different growth substances and confirms the overlapping effect of the cultivars with the resulting effect on the growth substances in these traits, and this overlap value will vary depending upon the cultivar and the degree of its response to the growth substances. The interaction between cultivars and growth substances has been reported before by Magdi (2011) which detected the significant differences between cultivar and spray growth substances treatment interaction for total green yield/plant.

\section{REFERENCES}

Abd el-Azeem, K. S.; E. H. El Harty; M. H. Ammar and S. S. Alghamdi(2014).Evaluation of faba bean (Vicia faba L.) performance under various micronutrients foliar applications and plant spacing. Life Sci. J.,11(10).

Anna Kocoń (2010).The effect of foliar or soil top-dressing of urea on some physiological processes and seed yield of faba bean. Polish J. of Agron, 3: 15-19.

Davood, H. (2013). Phosphorus fertilizers effect on the yield and yield components of faba bean (Viciafaba L.).Annals of Biolo. Res., 4 (2):181-184.

FAO STAT (3013).Faba bean, dry: the area harvested and productions. Food and Agriculture Organization of The United Nations 2013. 
Gomez, K.A. and A.A. Gomez (1984). Statistical Procedures For Agricultural Research (2 ed.). John wiley and sons, NewYork, $680 p$.

Hegazy, M. H.; D.Abadi and S. A. Genaidy(1992).Effects of some micronutrients, methods of application and rhizobium inoculation on faba bean.Egy.J.of Agric. Res., 70(4):1011-1023.

Hornykiewicz, O. (2010). "A brief history of levodopa". J. of Neurology 257 (S2):249-252. doi:10.1007/s00415-010-5741y. PMID 21080185.

Ibrahim M.E.; A.E.Moftah and A.A.Gendy (1995).Growth, flowering, abscission, endogenous, hormones, yield of broad bean (Vicia fabaL.) as affected by tebepas and zinc. Zagazig J. Agric. Res. 22(1):79-104.

Kandil, A.A.; A.E. Sharief and A.S.A. Mahmoud (2011).Reduction of flower dropping in some faba bean cultivars by growth regulators. Journal of Applied Sciences Research, 7(12): 18831889.

Khalil,N. A.; W. A. Al-Murshidy; A. M. Eman and R. A. Badawy (2015). Effect of plant density and calcium nutrition on growth and yield of some faba bean varieties under saline conditions. Of International Sci. Publications. 3 (1): 440-450.

Mady, M. A. (2009). Effect of foliar application with yeast extract and zinc on fruit setting and yield of faba bean (Viciafaba L).J. Biol. Chem.Environ. Sci., 4(2): 109-127.

Magdi, A. N. (2011).Effect of some foliar application on yield and its components in broad bean (Vicia faba L.). Egypt. J. Agric. Res., 89 (3); 1071

Mahmoud, M. S.; A. F. El-Sayed; E.Z.A. M. Aly and A.K. Mohamed (2006). Boron/nitrogen interaction effect on growth and yield of faba bean plants grown under sandy soil condition. Int. J. of Agri. Res. 1(4):322-330.

Sadak,Mervat, SH; M. G. Dawood; B.A. Bakry and M.F. El-Karamany (2013).Synergistic effect of indole acetic acid and kinetin on performance, some biochemical constituents and yield of faba bean plant grown under newly reclaimed sandy soil. World $\mathrm{J}$. of Agric. Sci. 9 (4): 335-344

Shehata, S. A. M. and M. A. Bondok (1996).Induction of pod setting and shedding reduction in faba bean (Vicia faba L.) by the auxin transport inhibitors TIBA and NPA. Ann. of Agric. Sci. Cairo, 41(1):35-49

Talaat,Neveen, B. and A.M.Abdallah (2008). Response of faba bean (Vicia faba L.) to dual inoculation with rhizobium and vamycorrhiza under different levels of $\mathbf{N}$ and $\mathbf{P}$ fertilization. J. of App. Sci. Res., 4(9): 1092-1102. 


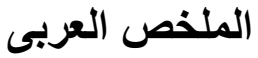

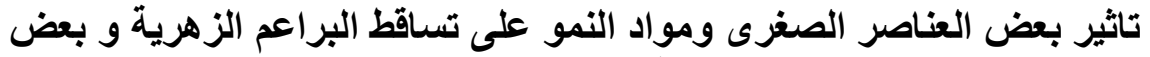

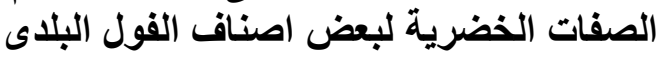
رمضان على الرفاعى" , اسامة عبدالحميد عبد الرازق3 ${ }^{1}$, عادل الجارحى محمد² , محمد

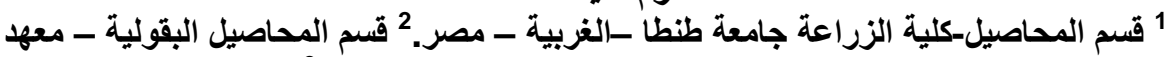

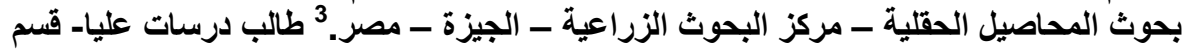

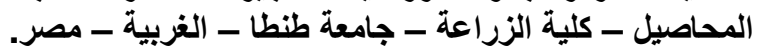

أجريت هذه الدراسة فى المزرعة البحثية لمحطة البحوث الزئل الزراعية بايتاى البارود , محافظة

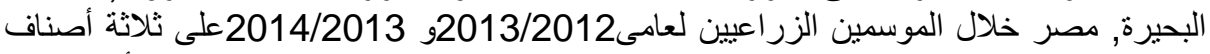

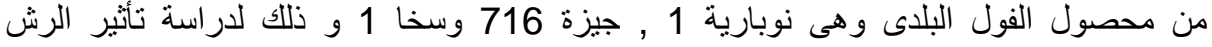

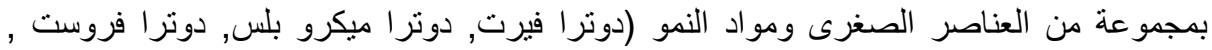
كروب بلس بالاضافة الى الكنترول )على بعض الصفري الصفات مثل اجمالى عدد الازهار , النسبة المئوية

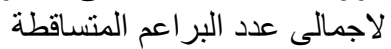

ومجموعة من صفات النمو الخضرى. تم زراعة اصناف الفول البلاى الثلاثة فى الموسم

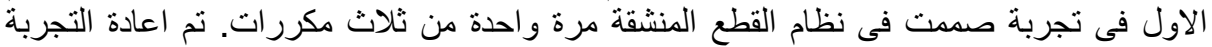

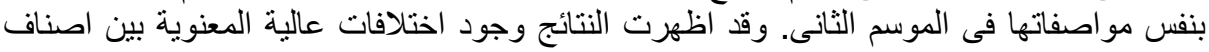

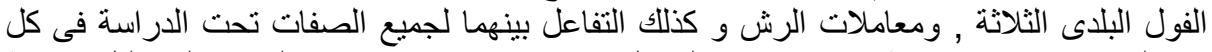

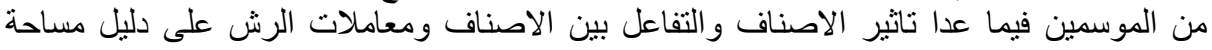

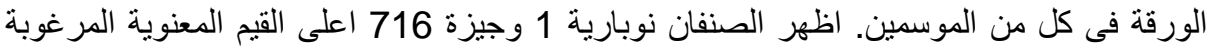

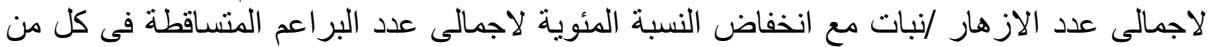

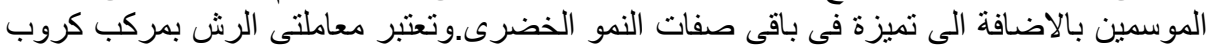

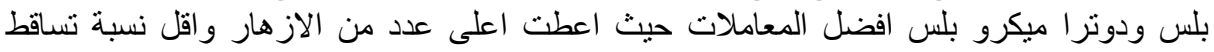

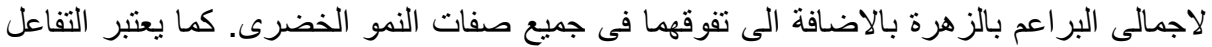

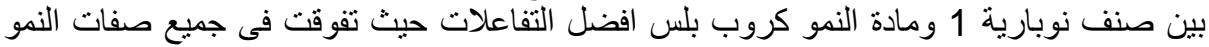

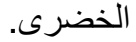

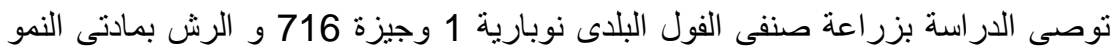

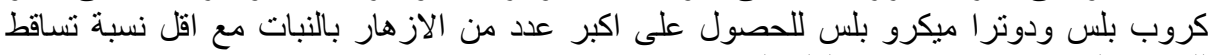

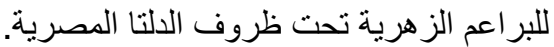


Table (2): Effect of cultivars, growth substances treatments and their interactions on vegetative traits (total flowers/ plant, percentage of buds shedding/plant, leaf area index, leaf fresh weight/plant(g), leaf dry weight/plant $(\mathrm{g})$, fresh stem weight/plant $(\mathrm{g})$ and dry stem weight/plant (g)) during 2013/2014 and 2014/2015 seasons

\begin{tabular}{|c|c|c|c|c|c|c|}
\hline \multirow[t]{2}{*}{ Factors } & \multicolumn{2}{|c|}{ No. of total flowers/ plant } & \multicolumn{2}{|c|}{$\begin{array}{c}\text { Percentage } \\
\text { of total buds shedding/plant }\end{array}$} & \multicolumn{2}{|c|}{ Leaf area index } \\
\hline & $2012 / 2013$ & $2013 / 2014$ & $2012 / 2013$ & $2013 / 2014$ & $2012 / 2013$ & $2013 / 2014$ \\
\hline \multicolumn{7}{|c|}{ Cultivar (A) } \\
\hline Nubaria 1 & 87.75 & 97.27 & 88.48 & 75.48 & 3.41 & 3.45 \\
\hline Giza 716 & 86.94 & 107.5 & 88.61 & 84.40 & 3.31 & 3.35 \\
\hline Sakha 1 & 86.94 & 99.21 & 87.16 & 78.93 & 3.34 & 3.39 \\
\hline F - test & $\star *$ & $* *$ & ** & $\star *$ & NS & NS \\
\hline LSD 0.01 & 0.780 & 3.707 & 0.667 & 1.494 & - & - \\
\hline \multicolumn{7}{|c|}{ Growth substance (B) } \\
\hline Control & 81.87 & 86.92 & 92.17 & 91.63 & 3.23 & 3.29 \\
\hline Crop plus & 94.68 & 114.4 & 84.94 & 82.04 & 3.52 & 3.60 \\
\hline Dotra frost & 83.75 & 96.2 & 77.01 & 76.07 & 3.28 & 3.30 \\
\hline Dotra micro plus & 90.57 & 108.1 & 89.02 & 84.33 & 3.39 & 3.46 \\
\hline Dotrafirt & 85.18 & 101 & 90.60 & 89.93 & 3.33 & 3.35 \\
\hline F - test & $\star \star$ & $\star \star *$ & $\star *$ & $\star \star$ & * & $\star *$ \\
\hline LSD 0.05 & - & - & - & - & 0.164 & - \\
\hline LSD 0.01 & 3.137 & 2.704 & 2.355 & 2.104 & - & 0.148 \\
\hline \multicolumn{7}{|c|}{ A B Interaction } \\
\hline F-test & $\star *$ & ** & ** & $\star \star$ & NS & NS \\
\hline
\end{tabular}

Table (2): Cont.

\begin{tabular}{|c|c|c|c|c|c|c|c|c|}
\hline \multirow[t]{2}{*}{ Factors } & \multicolumn{2}{|c|}{ Leaf fresh weight/plant(g) } & \multicolumn{2}{|c|}{ Leaf dry weight/plant(g) } & \multicolumn{2}{|c|}{$\begin{array}{c}\text { Fresh stem weight } \\
\text { /plant(g) }\end{array}$} & \multicolumn{2}{|c|}{$\begin{array}{l}\text { Dry stem weight } \\
\text { /plant(g) }\end{array}$} \\
\hline & $2012 / 2013$ & $2013 / 2014$ & $2012 / 2013$ & $2013 / 2014$ & 2012/2013 & $2013 / 2014$ & $2012 / 2013$ & $2013 / 2014$ \\
\hline \multicolumn{9}{|c|}{ Cultivar (A) } \\
\hline Nubaria 1 & 131.43 & 117.71 & 22.49 & 21.20 & 461.22 & 440.61 & 75.66 & 73.92 \\
\hline Giza 716 & 119.42 & 119.18 & 15.38 & 16.01 & 452.37 & 430.91 & 74.97 & 73.30 \\
\hline Sakha 1 & 131.08 & 128.37 & 20.64 & 20.19 & 471.33 & 457.34 & 75.46 & 76.40 \\
\hline$F$ - test & $* *$ & $* *$ & ${ }^{* *}$ & $\star *$ & NS & $* *$ & NS & ${ }^{* *}$ \\
\hline LSD 0.01 & 9.860 & 5.635 & 1.794 & 1.076 & - & 13.72 & - & 2.029 \\
\hline \multicolumn{9}{|c|}{ Growth substance (B) } \\
\hline Control & 88.10 & 83.25 & 10.70 & 9.78 & $374.29 \mathrm{~d}$ & 358.83 & 66.10 & 65.73 \\
\hline Crop plus & 184.28 & 175.68 & 32.24 & 31.59 & 575.62 & 542.28 & 87.93 & 85.87 \\
\hline Dotrafrost & 103.23 & 94.07 & 14.60 & 13.76 & 422.53 & 401.53 & 69.71 & 68.32 \\
\hline $\begin{array}{l}\text { Dotra micro } \\
\text { plus }\end{array}$ & 151.16 & 146.63 & 23.84 & 23.71 & 515.88 & 503.80 & 81.73 & 81.78 \\
\hline Dotrafirt & 109.78 & 109.13 & 16.13 & 16.82 & 419.85 & 408.32 & 71.34 & 70.99 \\
\hline $\mathrm{F}-$ test & $* *$ & & ${ }^{* *}$ & $* *$ & & $* *$ & $\star *$ & \\
\hline LSD 0.01 & 9.490 & 5.950 & 1.588 & 0.856 & 36.224 & 23.465 & 2.697 & 1.971 \\
\hline \multicolumn{9}{|c|}{ A B Interaction } \\
\hline$F-$ test & ** & & ${ }^{* \star}$ & ** & ** & ** & ** & ** \\
\hline LSD 0.01 & 21.687 & 10.305 & 2.751 & 1.482 & 49.541 & 36.146 & 5.092 & 3.413 \\
\hline
\end{tabular}


Table (3): Effect of the interaction between the three cultivars and the five fertilizers treatments for vegetative growth traits of faba bean

\begin{tabular}{|c|c|c|c|c|c|c|c|c|c|c|c|c|c|}
\hline \multirow{2}{*}{ Cultivars } & \multirow{2}{*}{ Treatments } & \multicolumn{2}{|c|}{$\begin{array}{c}\text { No. of total } \\
\text { Flowers/ Plant }\end{array}$} & \multicolumn{2}{|c|}{$\begin{array}{c}\text { Shedding } \\
\text { Percentage } \\
\text { of buds/plant }\end{array}$} & \multicolumn{2}{|c|}{$\begin{array}{l}\text { Leaf fresh } \\
\text { weight /plant(g) }\end{array}$} & \multicolumn{2}{|c|}{$\begin{array}{l}\text { Leaf dry weight/ } \\
\text { plant(g) }\end{array}$} & \multicolumn{2}{|c|}{$\begin{array}{c}\text { Fresh stem } \\
\text { weight /plant(g) }\end{array}$} & \multicolumn{2}{|c|}{$\begin{array}{l}\text { Dry stem } \\
\text { weight /plant(g) }\end{array}$} \\
\hline & & $S_{1}$ & $S_{2}$ & $S_{1}$ & $\mathbf{S}_{2}$ & $\mathbf{S}_{1}$ & $S_{2}$ & $\mathbf{S}_{1}$ & $S_{2}$ & $\mathbf{S}_{1}$ & $\mathrm{~S}_{2}$ & $\mathbf{S}_{1}$ & $S_{2}$ \\
\hline \multirow{5}{*}{ Nubaria 1} & Control & 83.75 & 81.25 & 91.44 & 63.05 & 85.95 & 73.18 & 11.7 & 10.53 & 367.98 & 346.73 & 66.35 & 65.1 \\
\hline & Crop Plus & 94.1 & 114.3 & 85.39 & 88.1 & 189.2 & 170.35 & 38.6 & 36.6 & 589.98 & 548.23 & 87.8 & 85.9 \\
\hline & Dotra Frost & 84.75 & 91.05 & 87.43 & 70.85 & $\begin{array}{c}107.3 \\
3\end{array}$ & 89.75 & 16.28 & 14.83 & 410.85 & 402.08 & 69.95 & 68.15 \\
\hline & $\begin{array}{l}\text { Dotra Micro } \\
\text { Plus }\end{array}$ & 90.05 & 105.65 & 88.08 & 81.95 & 160.9 & 142.05 & 27.65 & 24.68 & 524.25 & 499 & 82.4 & 79.55 \\
\hline & DotraFirt & 86.1 & 94.1 & 90.05 & 73.45 & $\begin{array}{c}113.7 \\
8\end{array}$ & 113.23 & 18.23 & 19.38 & 413.03 & 407 & 71.8 & 70.9 \\
\hline \multirow{5}{*}{ Giza 716} & Control & 81.9 & 91 & 92.98 & 71.85 & 84.95 & 80.13 & 9.4 & 9.33 & 375.7 & 343.45 & 67.03 & 64.93 \\
\hline & Crop Plus & 93.9 & 121.5 & 84.13 & 94.6 & 180.5 & 177.83 & 26.13 & 26.48 & 550.25 & 536.53 & 87.98 & 85.13 \\
\hline & Dotra Frost & 83 & 103.3 & 86.53 & 81.7 & 95.08 & 89.25 & 11.25 & 10.4 & 413.15 & 392.88 & 68.35 & 67.7 \\
\hline & $\begin{array}{l}\text { Dotra Micro } \\
\text { Plus }\end{array}$ & 90.55 & 114.05 & 89.12 & 88.9 & $\begin{array}{c}130.5 \\
5\end{array}$ & 146.58 & 17.4 & 20.83 & 501.43 & 481.68 & 80.93 & 78.2 \\
\hline & DotraFirt & 85.35 & 107.4 & 90.27 & 84.95 & 106 & 102.1 & 12.73 & 13 & 421.3 & 400 & 70.55 & 70.53 \\
\hline \multirow{5}{*}{ Sakha 1} & Control & 79.95 & 88.5 & 92.09 & 71 & 93.4 & 96.45 & 11 & 9.5 & 379.2 & 386.3 & 64.93 & 67.15 \\
\hline & Crop Plus & 96.05 & 107.4 & 85.32 & 84.43 & $\begin{array}{c}183.1 \\
3\end{array}$ & 178.88 & 32 & 31.7 & 586.63 & 542.1 & 88.03 & 86.58 \\
\hline & Dotra Frost & 83.5 & 94.25 & 87.08 & 75.65 & 107.3 & 103.2 & 16.28 & 16.05 & 443.6 & 409.63 & 70.83 & 69.1 \\
\hline & $\begin{array}{l}\text { Dotra Micro } \\
\text { Plus }\end{array}$ & 91.1 & 104.5 & 89.85 & 82.15 & $\begin{array}{c}162.0 \\
3\end{array}$ & 151.28 & 26.48 & 25.63 & 521.98 & 530.73 & 81.85 & 87.6 \\
\hline & DotraFirt & 84.1 & 101.4 & 91.48 & 81.4 & $\begin{array}{c}109.5 \\
5\end{array}$ & 112.05 & 17.43 & 18.08 & 425.23 & 417.95 & 71.68 & 71.55 \\
\hline \multicolumn{2}{|c|}{ LSD $1 \%$} & 5.434 & 3.234 & 3.778 & 3.645 & 21.68 & 10.31 & 2.75 & 1.48 & 49.54 & 36.15 & 5.09 & 3.41 \\
\hline
\end{tabular}

$\mathrm{S}_{1}, \mathrm{~S}_{2}$ first and second seasons 